\title{
ALLUVIAL MEADOWS OF CNIDION DUBII BAL.-TUL. 1966 IN THE MIDDLE ODER RIVER VALLEY (NATURA 2000 SITE "ŁĘGI ODRZAŃSKIE”, SW POLAND)
}

\begin{abstract}
AleKsandra Kazuń
A. Kazuń, Department of Nature and Rural Landscape Protection, Institute of Technology and Life Sciences, Falenty, al. Hrabska 3, 05-090 Raszyn, Poland, e-mail: olakazun@op.pl

(Received: January 9, 2014. Accepted: February 4, 2014)

ABSTRACT. The paper contains a phytosociological description and evaluation of alluvial meadows of Cnidion dubii Bal.-Tul. 1966 at the Natura 2000 site "Łęgi Odrzańskie", the middle Oder river valley, presented in relation to local water conditions and grassland management. Phytosociological data of the C. dubii alliance from Poland and the Czech Republic have also been presented.
\end{abstract}

KEY WORDS: alluvial meadows of Cnidion dubii, middle Oder river valley

\section{INTRODUCTION}

The study concerns alluvial meadows of the Cnidion dubii Bal.-Tul. 1966 alliance located in the Oder river valley between Brzeg Dolny and Głogów, at the Natura 2000 Habitats Directive Site "Lęgi Odrzańskie" (Lower Silesian and Lubusz Provinces). Due to the specificity of their habitats and species composition, Cnidion dubii meadows are very valuable elements of lowland river valleys' biodiversity. In Poland and other countries of the European Union, they are legally protected as habitat 6440 (ZAŁUSKI \& KĄCKI 2004). They have been identified relatively late as a phytosociological syntaxon. The $C$. dubii alliance was defined by Balátova-TuláčKova (1965); the data from Poland are presented mainly in the works by ZAeUSKI $(1995,1999)$. The middle Oder river valley is one of the most important areas in Poland with $C$. dubiii meadows (ZAŁUSKI \& KĄCKI 2004). They have been investigated by e.g. Bobrowicz (unpublished) during the research on natural resources of the "Lęgi Odrzańskie" site. The communities have been monitored by JeRMACZEK-SitAK (2008) in several localities within the scope of natural habitat monitoring conducted by the Institute of Nature Conservation, the Polish Academy of Sciences for the Chief Inspectorate of Environmental Protection (ZAluski 2010). In the area of the "Lęgi Odrzańskie" site, also meadow habitats have been monitored under agri-environmental schemes (JarzombKowski et al. 2013). In the present paper, phytosociological relevés from the above-mentioned project were used together with one data collected by the author for the plan of conservation tasks prepared for the "Łęgi Odrzańskie" site.

\section{STUDY AREA}

The section of the Oder river valley between Brzeg Dolny and Głogów is generally embanked; not embanked fragments with wide floodplains are located i.e. near Lubiąż and Ścinawa. The floodplains and areas between the dikes are covered mostly by meadows and alluvial forests. The grasslands are mown, rarely grazed; there are also many abandoned grasslands. Meadows and forests outside the embankments occur in a mosaic with arable lands.

At present, the Oder riverbed is significantly altered in relation to its natural morphology. Being an important waterway connecting Central, Southern and Western Europe, the Oder River has been engineered since the $18^{\text {th }}$ century (WYsOCKI 1981): the meanders have been straightened, the riverbed has been deepened, and the construction of groynes began in the $19^{\text {th }}$ century; the latter presently occur along the discussed river section. Deepening of the riverbed causes strong, deep erosion, further en- 
hanced by the impact of the barrage in Brzeg Dolny, operating since 1958. Furthermore, water retention in the Oder valley in Lower Silesia is reduced by the geological structure. The presence of very permeable quaternary sediments and deep cracking of the bedrock causes considerable losses in the surface and rainwater runoff (WALCZAK 1970).

The Oder River has two maximum water levels during the year: the lower one in spring, caused by melting of snow in the mountains, and the higher one in summer - usually in July - caused by rainwater (WalczaK 1970, Dubicki et al. 2005). At present, however, the water level drawdown in the river has become so strong that spring freshets are no longer significant in the discussed section; in fact, the water rarely reaches the floodplains. At the same time, the summer freshets have become catastrophic in recent years - flash floods of relatively short duration.

All the above factors contribute to a low groundwater level in the middle Oder river valley. Outside the flooding periods, the area becomes very dry. It has an adverse impact on the valley ecosystems, which is reflected in the terrestrialization of old riverbeds (oxbow lakes), desiccation of meadows and degradation of alluvial forests (ZAJĄC et al. 2008).

\section{MATERIALS AND METHODS}

Field studies were carried out in 18 C. dubii meadows from June to September 2012. The conservation status of nine meadows was assessed on 0.2 ha transects according to the list of indicators, parameters and methods developed by the Institute of $\mathrm{Na}$ -

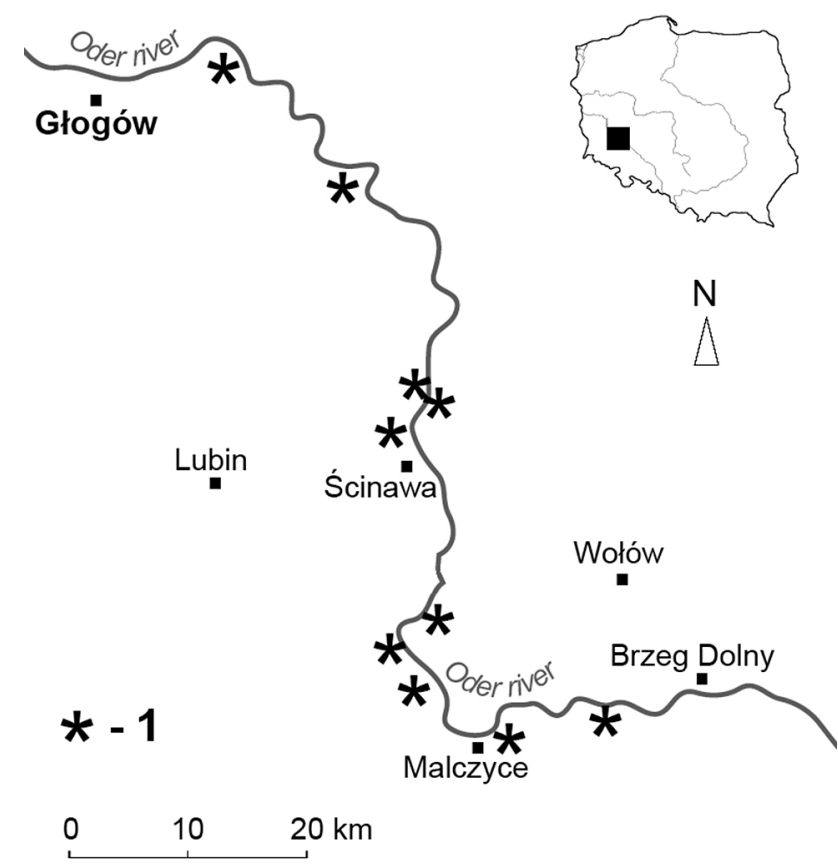

Fig. 1. Distribution of investigated Cnidion dubii meadows in the middle Oder river valley; 1 - occurrence sites of Cnidion dubii meadows ture Conservation of the Polish Academy of Sciences (ZAŁUSKI 2012). Phytosociological relevés according to the Braun-Blanquet method were made in eight meadows (relevés' authors: M. Braun, M. Jermaczek-Sitak, A. Kazuń). The distribution of the investigated plant communities is presented in Figure 1.

The names of plant taxa follow the checklist of vascular plants and pteridophytes of Poland (MireK et al. 2002).

\section{RESULTS}

\section{DESCRIPTION OF PLANT COMMUNITIES}

The investigated plant communities of the $C$. dubii alliance were divided into two categories, different in floristical and ecological terms. The species composition of the communities is presented in Table 1.

\section{COMMUNITIES LOCATED WITHIN THE ODER EMBANKMENTS AND IN OPEN FLOODPLAINS}

The first category includes plant communities strongly affected by the Oder flooding, mainly by the summer floods (Table 1, column A). The species composition is fairly impoverished - often less than 10 species occur per relevé, on average 11 species. The communities are characterised by Allium angulosum occurring with high constancy. Pink flowers of the species distinguish the patches in the mosaic of grasslands. Cnidium dubium was found at only one site; other characteristic species of the $C$. dubii alliance were absent, but differential species occurred abundantly: Carex praecox and Poa angustifolia. Furthermore, the vegetation is dominated by species of riverine grasslands from the Agropyro-Rumicion crispi alliance (mainly Potentilla reptans and $P$. anserina) and invasive species: Elymus repens and Cirsium arvense.

The communities can be identified as the subassociation Violo-Cnidietum dubii Walther in R. Tx. 1954 (n. inv.) subass. typicum. The subassociation was identified from similar habitats in the Oder and Warta river valleys (ZAŁUSKI 1995).

\section{COMMUNITIES LOCATED OUTSIDE THE ODER EMBANKMENTS AND IN WOODED FLOODPLAINS}

The second category are plant communities occurring outside the Oder embankments, flooded by water infiltrating under the dikes or by groundwater (Table 1, column B). The category also includes the meadows on the left Oder bank at the Lubiąż meander with wide, not embanked floodplains. The relief and riverine forest complexes along the riverbed slow down both the inflow and the outflow of flood waters. The communities of this group are considerably richer in species - sometimes the number of species in 
Table 1. Plant communities of the Cnidion dubii alliance at the Natura 2000 site "Łęgi Odrzańskie". A - communities located within the Oder embankments and open floodplains, B - communities located outside the Oder embankments and wooded floodplains

\begin{tabular}{lcc}
\hline Category of communities & A & B \\
Number of relevés & 11 & 12 \\
\hline
\end{tabular}

I ChAll. et DAll.* Cnidion dubii

Allium angulosum

Cnidium dubium

Viola stagnina

Poa angustifolia*

Carex praecox*

\begin{tabular}{|rr|rr|}
\hline V & 677 & II & 12 \\
\hline I & 159 & IV & 1625 \\
& & II & 158 \\
\hline V & 686 & V & 1237 \\
V & 4073 & IV & 2962 \\
\hline
\end{tabular}

II ChAll. et DAll.* Molinion

Serratula tinctoria*

Inula salicina

Silaum silaus

III ChO. Molinietalia

Alopecurus pratensis

Sanguisorba officinalis

Deschampsia caespitosa

Lychnis flos-cuculi

Lysimachia vulgaris

\begin{tabular}{|rr|}
\hline II & 154 \\
II & 54 \\
I & 8 \\
\hline
\end{tabular}

Euphorbia lucida

$\begin{array}{rrrr}\text { III } & 341 & \text { IV } & 1667 \\ \text { II } & 173 & \text { III } & 208 \\ \text { I } & 9 & \text { I } & 83 \\ & & \text { II } & 17 \\ & & \text { I } & 187 \\ & & \text { I } & 42\end{array}$

IV ChCl. Molinio-Arrhenatheretea

Potentilla reptans

Agrostis stolonifera

Inula britannica

Carex hirta

Rumex crispus

Potentilla anserina

Ranunculus repens

Lysimachia nummularia

Lathyrus pratensis

Vicia cracca

Rumex acetosa

Leucanthemum vulgare

Achillea millefolium

Campanula patula

Taraxacum sp.

Plantago lanceolata

Phleum pratense

Trifolium dubium

Cerastium holosteoides

Festuca rubra

\begin{tabular}{|rr|}
\hline III & 900 \\
II & 368 \\
II & 391 \\
II & 182 \\
\hline
\end{tabular}

I 4

II 59

59

212

III

554

III

68

V ChCl. Festuco-Brometea et ChCl.* Trifolio-Geranietea

Allium oleraceum

Euphorbia cyparissias

Filipendula vulgaris

Agrimonia eupatoria*

Galium verum*

I

III

I
VI ChCl. Agropyretea

Elymus repens

Equisetum arvense

Convolvulus arvensis 
Table 1. cont.

\begin{tabular}{|c|c|c|c|c|}
\hline Category of communities & A & & $\mathrm{B}$ & \\
\hline Number of relevés & 11 & & 12 & \\
\hline \multicolumn{5}{|l|}{ VII ChCl. Artemisietea } \\
\hline Cirsium arvense & II & 954 & III & 237 \\
\hline Carduus crispus & & & II & 12 \\
\hline Symphytum officinale & & & II & 54 \\
\hline Tanacetum vulgare & I & 4 & II & 12 \\
\hline Urtica dioica & $\mathrm{I}$ & 4 & I & 8 \\
\hline Agropyron caninum & $\mathrm{I}$ & 164 & & \\
\hline \multicolumn{5}{|l|}{ VIII Others } \\
\hline Phalaris arundinacea & $\mathrm{I}$ & 9 & $\mathrm{I}$ & 8 \\
\hline Prunus spinosa & I & 4 & I & 4 \\
\hline Vicia hirsuta & & & III & 204 \\
\hline Thalictrum lucidum & & & II & 50 \\
\hline Agrostis capillaris & & & I & 562 \\
\hline Calamagrostis epigejos & & & $\mathrm{I}$ & 46 \\
\hline Veronica arvensis & & & $\mathrm{I}$ & 46 \\
\hline Valerianella olitoria & & & $\mathrm{I}$ & 41 \\
\hline Carex disticha & & & $\mathrm{I}$ & 41 \\
\hline Quercus robur & & & I & 8 \\
\hline Hypericum perforatum & & & $\mathrm{I}$ & 8 \\
\hline
\end{tabular}

Sporadic species:

II - Betonica officinalis B (I4), Selinum carvifolia B (I4);

III - Cirsium palustre A (I4), Filipendula ulmaria B (I4), Poa palustris A (I4);

IV - Centaurea jacea B (I4), Daucus carota B (I4), Leontodon autumnalis A (I4), Lysimachia nummularia A (I4), Plantago major B (I4), Poa pratensis A (I4), Ranunculus acris B (I4), Rumex crispus B (I4), Trifolium pratense B (I4), Trifolium repens A (I4);

VII - Linaria vulgaris B (I4), Rubus caesius B (I4), Solidago canadensis B (I4), Solidago gigantea A (I4), Torilis japonica B (I4);

VIII - Acer sp. B (I4), Carex acutiformis B (I4), Carex vesicaria A (I4), Centaurium erythraea B (I4), Epilobium tetragonum A (I4), Erigeron acris B (I4), Erigeron annus B (I4), Ficaria verna B (I4), Filago vulgaris A (I4), Humulus lupulus A (I4), Galeopsis pubescens B (I4), Matricaria maritima B (I4), Myosotis ramossisima B (I4), Polygonum amphibium A (I4), Potentilla argentea B (I4), Ranunculus auricomus B (I4), Rumex acetosella B (I4), Trifolium arvense $A$ (I4), Viola canina $B$ (I4), Viola riviniana $B$ (I4).

a relevé is above 20 , the average number is 18 species - and significantly differ from the former in floristical aspects. Characteristic species of the C. dubii alliance are represented by Cnidium dubium which occurs frequently and abundantly; the constancy of Allium angulosum is lower. Also differential species of the alliance occur quite abundantly: Carex praecox, Poa angustifolia and Viola stagnina - a rare species in Lower Silesia. Other characteristics that distinguish these communities from the former category are as follows: the presence of Molinia meadow species (such as Silaum silaus, Selinum carvifolia, Serratula tinctoria, Inula salicina), more frequent and more abundant occurrence of meadow species typical of the Molinietalia order and the Molinio-Arrhenatheretea class (Alopecurus pratensis, Sanguisorba officinalis, Lathyrus pratensis, Leucanthemum vulgare) and the occurrence of Galium verum and other thermophilous species (such as Filipendula vulgaris, Allium vineale). The percentage of invasive species is a little lower compared to the previous category (although it is still high) and the overgrown parts of meadows are still of high natural value. They are covered by Sanguisorba officinalis, so they become perfect habitats for the protected butterfly species: Maculinea nausithous and M. teleius; Euphorbia lucida - a species rare in Lower Silesia and typical for large river valleys - is also common.

The communities correspond to the subassociation Violo-Cnidietum dubii Walther in R. Tx. 1954 (n. inv.) subass. galietosum veris T. Załuski 1995 related to sites moderately wet and periodically dry, but they are less rich in species than phytocenoses described by ZAŁUsKi (1995) from south-western Poland.

\section{PRESERVATION OF THE CNIDION DUBII MEADOWS}

More than a half, i.e. $56 \%$ of the $C$. dubii meadows observed at the Natura 2000 site "Łęgi Odrzańskie" are neither mown nor grazed. Abandoned grasslands are particularly common in the area between the Oder embankments. A few meadows are covered by the agri-environmental scheme, variant 5.4 Molinion and $C$. dubii meadows, which means that they are mown every two years after 15 September. One meadow is covered by variant 5.1 breeding bird habitats, therefore it is mown every year after $1 \mathrm{Au}-$ 
gust. Three meadows ( $17 \%$ of all sites) were mown in early summer (June-July) after flooding; they are not used for agri-environmental payments, but traditionally for cattle fodder.

\section{CONSERVATION STATUS OF THE HABITAT}

The conservation status of habitat 6440 in the meadows mown in June-July has been evaluated as favourable $-\mathrm{FV}$. The percentage of invasive species is relatively high, and this is partly related to the topography of the ground with frequent depressions which make the accurate mowing difficult. Nevertheless, the patches mown in early summer are distinguished by the well-developed vegetation structure, rich species composition and high percentage of characteristic and valuable species, including the abundant occurrence of Cnidium dubium, Allium angulosum, Viola stagnina and Euphorbia lucida - rare and threatened species in Lower Silesia (KACKI et al. 2003). The communities correspond to the subassociation Violo-Cnidietum dubii galietosum veris (Table 1 , column $\mathrm{B}$ ). The most valuable, well developed, large meadows are located near Malczyce in the meander of the Średzka Woda river.

Although the meadow covered by variant 5.1 breeding bird habitats is characterised by a high percentage of characteristic and typical species of the C. dubii alliance, changes in the vegetation structure are relatively significant and consist mainly of the encroachment of invasive species and accumulation of dead organic matter, which indicate that the meadow is mown too rarely or too late. The conservation status and perspectives of the patch have been evaluated as unsatisfactory (U1).
The conservation status of abandoned meadows has been evaluated as unsatisfactory (U1) or bad (U2), depending on the encroachment of invasive species (native or alien, such as Solidago gigantea), accumulation of dead organic matter, changes in the habitat spatial structure and the decline of characteristic species. In some cases, the conservation perspectives are assessed higher than the other parameters if water conditions of a site are favourable and the conservation status can be easily improved by implementation of regular mowing or grazing.

Evaluation of particular indicators and parameters for the meadows mown in different periods and meadows not mown are presented in Table 2 .

\section{DISCUSSION}

\section{PHYTOSOCIOLOGICAL REFERENCES}

Although the presented phytosociological data are rather scanty, they are consistent with the results of research on $C$. dubii communities conducted in Poland and the Czech Republic (ZAŁUsK 1995, 1999, Šumberová $2007 \mathrm{a}, \mathrm{b})$, and particularly in western Poland (Jermaczek-SitAK 2008, 2011). The research confirms that a group of communities can be distinguished in the C. dubii meadows associated with the sites strongly affected by flooding, such as large floodplains. The communities are optimal habitats for Allium angulosum; they are also characterised by high cover of Elymus repens and species of the Agropyro-Rumicion crispi alliance. The species composition is sometimes very impoverished, which is probably caused by highly selective flooding influence (JERMACZEK-SITAK 2011). Such communities have been

Table 2. Evaluation of the conservation status of Cnidion dubii meadows according to indicators and parameters developed by INC PAS; 1 - meadows mown in June-July, 2 - meadow mown after 1 August (variant 5.1 breeding bird habitats), 3 - abandoned meadows

\begin{tabular}{|c|c|c|c|c|c|c|c|c|c|}
\hline \multirow{2}{*}{$\begin{array}{l}\text { Indicator } \\
\text { Habitat area }\end{array}$} & \multicolumn{2}{|c|}{1} & \multirow{2}{*}{$\begin{array}{c}2 \\
\mathrm{FV}\end{array}$} & \multicolumn{6}{|c|}{3} \\
\hline & $\mathrm{FV}$ & FV & & $\mathrm{FV}$ & U1 & U1 & FV & $\mathrm{FV}$ & $\mathrm{FV}$ \\
\hline Characteristic species & FV & $\mathrm{FV}$ & $\mathrm{FV}$ & FV & $\mathrm{U} 2$ & FV & FV & $\mathrm{FV}$ & $\mathrm{U} 2$ \\
\hline Dead organic matter & $\mathrm{FV}$ & $\mathrm{FV}$ & U1 & U1 & $\mathrm{U} 2$ & U1 & U1 & $\mathrm{U} 2$ & $\mathrm{U} 2$ \\
\hline Dominant species & $\mathrm{FV}$ & $\mathrm{FV}$ & U1 & U1 & U1 & $\mathrm{U} 2$ & $\mathrm{U} 2$ & $\mathrm{FV}$ & U1 \\
\hline Invasive alien species & U1 & $\mathrm{FV}$ & $\mathrm{FV}$ & $\mathrm{U} 2$ & FV & U1 & U1 & $\mathrm{FV}$ & $\mathrm{FV}$ \\
\hline Invasive native species & U1 & U1 & U1 & U1 & $\mathrm{U} 2$ & $\mathrm{U} 2$ & $\mathrm{U} 2$ & $\mathrm{U} 2$ & $\mathrm{U} 2$ \\
\hline Local specificity of the habitat & $\mathrm{FV}$ & FV & FV & U1 & $\mathrm{U} 2$ & $\mathrm{U} 2$ & $\mathrm{U} 2$ & $\mathrm{U} 1$ & $\mathrm{U} 2$ \\
\hline Spatial structure of the habitat & $\mathrm{FV}$ & FV & FV & FV & $\mathrm{U} 2$ & $\mathrm{U} 2$ & U1 & U1 & U1 \\
\hline Succession of shrubs and trees & FV & FV & FV & FV & $\mathrm{FV}$ & $\mathrm{FV}$ & U1 & $\mathrm{FV}$ & FV \\
\hline Valuable plant species & $\mathrm{FV}$ & $\mathrm{FV}$ & FV & $\mathrm{FV}$ & U1 & U1 & $\mathrm{FV}$ & $\mathrm{FV}$ & U1 \\
\hline \multicolumn{10}{|l|}{ Parameter } \\
\hline Structure and functions & FV & FV & U1 & U1 & $\mathrm{U} 2$ & $\mathrm{U} 2$ & $\mathrm{U} 2$ & U1 & $\mathrm{U} 2$ \\
\hline Conservation perspectives & $\mathrm{FV}$ & FV & U1 & U1 & U1 & $\mathrm{U} 1$ & $\mathrm{U} 2$ & U1 & $\mathrm{U} 1$ \\
\hline Overall evaluation & $\mathrm{FV}$ & $\mathrm{FV}$ & U1 & U1 & $\mathrm{U} 2$ & $\mathrm{U} 2$ & $\mathrm{U} 2$ & U1 & $\mathrm{U} 2$ \\
\hline
\end{tabular}

FV - favourable, U1 - unsatisfactory, U2 - bad. 
defined by ZAŁUSKI (1995) as the subassociation Violo-Cnidietum dubii typicum.

The other category includes floristically richer communities, with typical meadow species of Molinietalia and Arrhenatheretalia orders and with species of the Molinion alliance. The characteristic species of C. dubii are represented mainly by Cnidium dubium. The phytocenoses are found in areas where flooding influence is not so strong, i.e. farther away from the river or behind the dikes. In addition to river flooding, they are also flooded by groundwater (Š́UMBEROVÁ 2007 b, JeRMACZeK-SitaK 2008, 2011). ZaeUSKi (1995) defines the category of communities as the subassociation Violo-Cnidietum dubii galietosum veris. Probably it also corresponds to the association Cnidio dubii-Deschampsietum cespitosae defined by Šumberova (2007 b), although the author did not find Galium verum in the patches.

\section{SPECIFICITY OF CNIDION DUBII MEADOWS IN THE MIDDLE ODER RIVER VALLEY}

The $C$. dubii meadows in the middle Oder river valley are characterised by high cover of xerothermic species: Elymus repens and Carex praecox, observed also by JERMACZEK-SitAK (2011). The occurrence of the above species is typical for plant communities in river valleys, but in no other area of Poland they have been observed so abundantly (ZAŁUSKI 1995, 1999). The phenomenon is probably related to the characteristics of the valley. Due to engineering of the river, deepening of the riverbed and deep erosion, the groundwater level in the riverside areas is generally low. In the periods of low water levels, the areas become very dry. The flooding events, though sometimes rapid, usually do not last long, even within the river embankments. In the investigated area, hygrophilous C. dubii communities have not been found; they require longer periods of submergence, such as the subassociation Violo-Cnidietum dubii stellarietosum palustris (ZAŁUSKI 1995, 1999), or Lathyro palustris-Gratioletum officinalis (ŠUmberová 2007 a).

\section{CONSERVATION ISSUES}

As evidence by the observations of $C$. dubii meadows at the Natura 2000 site "Łęgi Odrzańskie", the plant communities are preserved in a very good state, while they are affected by traditional extensive use in the form of mowing in early summer (June-early July). Therefore, the late autumn mowing recommended for the agri-environmental variant 4.4/5.4 Molinion and C. dubii meadows is not favourable for 6440 habitat. Furthermore, the late autumn mowing may induce the spread of invasive species and is not profitable for an owner, as the autumn hay is not suitable as cattle fodder.

\section{MAJOR THREATS}

The main and the most common threat to habitat 6440 at the Natura 2000 site "Łęgi Odrzańskie" is abandonment of grasslands and, consequently, intrusion of invasive species and shrubs. It is particularly evident in the flooding areas within the embankments of the Oder river.

\section{REFERENCES}

Balátová-TuláčKová E. (1965): Cnidion venosi, ein neuer Molinietalia verband (vorläufige Mitteilung). Biológia 20(4): 294-296.

Dubicki A., Radczuk L., Adynkiewicz-Piragas M., Tokarczyk T., Mordalska H., Maciejowska B., Lisowski J., Bogusz A., Krzyścin K. (2005): Wody powierzchniowe. Rozdział 6. In: Opracowanie ekofizjograficzne dla województwa dolnośląskiego. Adres URL: http://eko.wbu.wroc.pl/eko/index.php? option $=$ com_content $\&$ task $=$ category\&sectionid $=2 \& i d=10 \&$ Itemid $=8$.

Jarzombkowski F., Goldstein K., Gutowska E., Kazuń A., Kotowska D., Kotowska K., Kowalska M., Krajewski Ł., Piórkowski H., Szczepaniuk A., ŻMIHORSKI M. (2013): Monitoring siedlisk pakietów przyrodniczych programu rolnośrodowiskowego 2012-2015. Sprawozdanie końcowe z roku 2012. Typescript. Instytut Technologiczno-Przyrodniczy w Falentach.

Jermaczek-Sitak M. (2008): Cenne elementy kompleksu łąk zmiennowilgotnych $\mathrm{w}$ dolinie Odry pod Nową Solą. Przegląd Przyrodniczy 19, 3-4: 77-85.

JeRMACZEK-SitAK M. (2011): Charakter i stan zachowania łąk selernicowych Cnidion w zachodniej Polsce a warunki wodne. Przegląd Przyrodniczy 22, 3: 83-90.

KĄCKI Z., DAjDOK Z., SZCZĘ́́NIAK E. (2003): Czerwona lista roślin naczyniowych Dolnego Śląska. In: Z. Kącki (ed.). Zagrożone gatunki flory naczyniowej Dolnego Śląska. Polskie Towarzystwo Przyjaciół Przyrody „pro Natura”, Wrocław.

Mirek Z., PięKoś-Mirkowa H., Zają̨c A., Zając M. (2002): Flowering plants and pteridophytes of Poland - a checklist. Vol. 1. Biodiversity of Poland - Krytyczna lista roślin naczyniowych Polski. T. 1. Różnorodność biologiczna Polski. Institute of Botany, Polish Academy of Sciences, Kraków.

ŠumBerová K. (2007 a): TDE03 Lathyro palustris-Gratioletum officinalis Balátová-Tuláčková 1966. In: M. Chytrý (ed.). Vegetace České republiky. 1. Travinná a keř́čcková vegetace [Vegetation of the Czech Republic. 1. Grassland and Heathland Vegetation]. Academia, Praha: 229-232.

Šumberová K. (2007 b): TDE04 Cnidio dubii-Deschampsietum cespitosae Passarge 1960. In: M. Chytrý (ed.). Vegetace České republiky. 1. Travinná a keřričková 
vegetace [Vegetation of the Czech Republic. 1. Grassland and Heathland Vegetation]. Academia, Praha: 233-236.

WALczaK W. (1970): Obszar przedsudecki. PWN, Warszawa.

WYsocki W. (1981): Mapy i plany zarządu regulacji rzeki Odry (XVIII-XIX w.). Archeion 71: 109-122 .

ZAŁUski T. (1995): Łąki selernicowe (związek Cnidion dubii Bal.-Tul. 1966) w Polsce. Monographiae Botanicae 77.

ZAŁUSKI T. (1999): Specyfika florystyczna łąk selernicowych w Polsce. Folia Universitatis Agriculturae Stetinensis 197, Agricultura 75: 363-366.

ZAŁUski T. (2010): 6440 Łąki selernicowe (Cnidion dubii). In: G. Cierlik, M. Makomaska-Juchiewicz, W.
Mróz, J. Perzanowska, W. Król, P. Baran, A. Zięcik (eds). Sprawozdanie z prac monitoringowych w roku 2010. T. 1. Instytut Ochrony Przyrody PAN, Kraków: 182-200.

ZAŁUSKI T. (2012): 6440 Łąki selernicowe (Cnidion $d u-$ bii). In: W. Mróz (ed.). Monitoring siedlisk przyrodniczych. Przewodnik metodyczny. Cz. 3. GIOŚ, Warszawa: 64-78.

ZAŁUSKI T., KĄCKI Z. (2004): Łąki selernicowe (Cnidion dubii). In: J. Herbich (ed.). Murawy, łąki, ziołorośla, wrzosowiska, zarośla. Poradniki ochrony siedlisk i gatunków Natura 2000 - podręcznik metodyczny. T. 3. Ministerstwo Środowiska, Warszawa: 185-191. 